\title{
Note on MS Vlatadon 14: a Summary of the Main Findings and Problems
}

\author{
P. N. Singer
}

The Galenic manuscript fortuitously discovered by Antoine Pietrobelli in a Greek monastery in 2005 contains four items with significant new Galenic material: an entire text which had previously been lost to us, $\pi \varepsilon p i$ à $\lambda u \pi i a s$ (Ind.); the full Greek text of a work which had been available in Greek only in small part, the rest having to be supplied from an Arabo-Latin and a Graeco-Latin translation, My Own Doctrines (Prop. Plac.); ${ }^{1}$ and an additional version of the Greek text of two works which were already extant, but with significant lacunae, in the only previously-known Greek manuscript, My Own Books (Lib. Prop.) and The Order of My Own Books (Ord. Lib. Prop.). ${ }^{2}$

In the case of the last two works mentioned, then, the Vlatadon manuscript was able to fill these lacunae. The discovery of the wholly new text, $\pi \varepsilon p i \dot{\alpha} \lambda u \pi i a \varsigma$, has given rise to a veritable flurry of international scholarly activity, including both a great deal of philological work on problems in the text and a number of analyses of the new light - and of the questions and puzzles - which the text sheds and raises. Meanwhile, the full Greek version of My Own Doctrines has attracted some, though comparatively much less, attention; and discovery of some missing sentences from the two works of auto-bibliography, My Own Books and The Order of My Own Books, has gone more or less unnoticed. In

1 The editio princeps of the partial Greek text supplemented by Latin sources was produced by Nutton, V. (1999). Galen: De propriis placitis, and that of the full Greek text, with French translation, by Boudon-Millot, V. and Pietrobelli, A. (2005). 'Galien ressucité: édition princeps du texts grec du De propriis placitis', Revue des Études Grecques 118, 168-213; the latter scholar is preparing a full critical edition of the text. See Nutton's edition, 14-45 and Pietrobelli, A. (2013). 'Galien agnostique: un texte caviardé par la tradition', Revue des Études Grecques 126, 103-35, at 106-9, for further detail on the textual tradition (which also includes a section in Hebrew translation).

2 A peculiarity of the nature of the damage to the single previously known manuscript of these two texts that it gave rise to lacunae covering significantly overlapping material in the two texts, which both list Galen's own works. The edition and translation of Boudon-Millot, V. (2007). Galien, Tome 1, takes account of the new material; see also Boudon-Millot V. (2014). 'Vlatadon 14 and Ambrosianus Q3: Two Twin Manuscripts'. In Rothschild, C. K. and Thompson, T. W. (eds) Galen's De indolentia, $41-55$.

(C) P. N. SINGER, 2019 | DOI:10.1163/9789004383302_003

This is an open access chapter distributed under the terms of the prevailing CC-BY-NC-ND License at the time of publication. 
view of the wealth of scholarly publications that have already appeared, in a wide range of different languages, books and journals - and especially in view of the fact that in some cases these have appeared after the publication of the critical editions of $\pi \varepsilon p i \dot{\alpha} \lambda v \pi i a s$, or at least too late to be fully taken into account by their various editors - it may be helpful to offer an overview both of the new information and fresh insights that have accrued from research on the manuscript thus far, and of the chief problems and areas of dispute. This chapter attempts such an overview, considering both the main research findings and controversies and, in the context of a highly problematic and already much discussed manuscript, the most significant and/or debated textual cruces in the text of $\pi \varepsilon p i \dot{\alpha} \lambda v \pi i a s$.

\section{Main Findings}

The main gains and research findings arising from the discovery may, I think, be listed under five heads or topics:

(i) archaeology: the location, and nature, of Roman libraries and storehouses in the imperial period;

(ii) scholarship and bibliographical practice: specific features of manuscript collection and scholarly traditions in second-century-AD Rome, as well as the nature of book production and book distribution;

(iii) Galen's practices of book-study and of book-composition;

(iv) moral philosophy: Galen's contribution to the genre;

(v) Galen's summation of, and attitude to, his own central philosophical doctrines.

While the text of $\pi \varepsilon p i \dot{\alpha} \lambda v \pi i a \varsigma$ sheds new light on topics (i) and (iv) above, both this and the texts of My Own Books and The Order of My Own Books shed light on topics (ii) and (iii). ${ }^{3}$

A considerable amount of recent scholarship has been devoted to (i), exploring the location and nature of both the public imperial library collections mentioned by Galen and his own private storehouse, as well as the nature and extent of the damage inflicted in this geographical area by the fire of 192. Some clarity has emerged - we seem for example to have a fairly clear idea of the

3 But the list is not exhaustive. Another debate re-ignited by the codex concerns the vexed question of Galen's gentilicium: is it possible that he was called Claudius after all? See Alexandru, S. (2011). 'Newly Discovered Witness Asserting Galen's Affiliation to the Gens Claudia', Annali della Scuola Normale Superiore di Pisa, ser. 5, 3/2, 385-433 and Nutton, V. (2015). 'What's in a Nomen? Vlatadon 14 and an Old Theory Resuscitated', in Holmes, B. and Fischer, K.-D. (eds), The Frontiers of Ancient Science: Essays in Honour of Heinrich von Staden, 451-62. 
location of Galen's own storehouse, in the Horrea Pipertaria - but there remain significant uncertainties in relation to library locations, arising from the highly problematic nature of certain passages of the Greek text. That a library attached to the Temple of Peace was one of the major ones destroyed in the fire is clear; a library attached to Tiberius' palace is also mentioned; but a problem arises in the relevant passage (sections 12b-18), as to the precise location, and number, of the libraries to which Galen is referring when he mentions the 'Palatine' (or 'palace') libraries; and a particularly thorny problem as to the location indicated by Galen's reference to a further set of book losses, not by fire but by damp and looting (and possibly rodent damage). Is he here referring to library location in a marshy place in the Forum (and if so, precisely where), or rather to a library not at Rome at all but in Antium?' (See further below for the problematic passage of text from which this debate arises.)

On topic (ii) - obviously related to (i), but touching on broader questions in the history of texts and intellectual traditions, as well as the history of the book as a physical object - there has been even more activity; 5 and here too areas of clarity are counterbalanced by considerable uncertainties of interpretation. Among the results that have emerged with clarity we may mention: the existence of a range of texts, most especially but not only in the Aristotelian tradition, ${ }^{6}$ that were not previously known to be available to or of interest to Galen;

4 A clear overview, of likely geographical situations and of the recent debate and the problems, is given by Nutton (2013). Avoiding Distress, in Singer, P. N. (ed.) Galen: Psychological Writings, 53-61. See also Dix, T. K. and Houston, G. W. (2006). 'Public Libraries in the City of Rome: From the Augustan Age to the Time of Diocletian', Mélanges de l'École Française de Rome: Antiquité 118:2, 671-717; Houston, G. W. (2008). 'Galen, His Books and the Horrea Pipertaria at Rome', Memoirs of the British Academy in Rome 48 (2008), 45-51; Tucci, P. L. (2008). 'Galen's Storeroom, Roman Libraries, and the Fire of AD 192', JRA 21, 133-49; id. (2009). 'Antium, the Palatium and the Domus Tiberiana Again' JRA 22, 398-401; id. (2013). 'Galen and the Library at Antium: The State of the Question', Classical Philology 108:3, 240-51; Jones, C. P. (2009). 'Books and Libraries in a Newly-Discovered Treatise of Galen', JRS 22, 390-7; Rothschild, C. K. and Thompson, T. W. (2011). 'Galen's On the Avoidance of Grief: The Question of a Library at Antium', Early Christianity 2.1, 110-29; cf. Boudon-Millot, V. and Jouanna, J. (2010). Galien, Oeuvres 4: Ne pas se chagriner, xxii-xxvii and 66; Nicholls, M. 'A Library at Antium?', in Rothschild, C. K. and Thompson, T. W. (2013). Galen's De indolentia, 65-78.

5 See Nutton, Avoiding Distress and Manetti, D. (ed.) (2012). Studi sul De indolentia di Galeno; further bibliography on specific debates in relation to cruces is given below.

6 The focus on and engagement with Aristotle and Aristotelians - and, more specifically, firstgeneration Aristotelians - is emphasized by the grouping, 'Theophrastus, Aristotle, Eudemus, Clytus and Phaenias' at the beginning of the list of examples of works whose manuscripts Galen had carefully corrected to create a new edition, at 15, 6,18-19 BJP. The point is made by Rashed, M. (2011). 'Aristote à Rome au IIe siécle: Galien, De indolentia $§ \S 15^{-18}$ ', Elenchos $32,57-8$ (arguing convincingly for following more closely the Ms reading $x \lambda i$ i ov, against

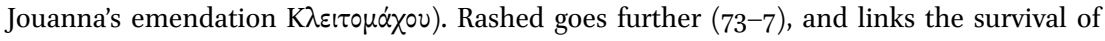


and the nature of his own use of material from such particular collections, ranging from intensive study and collation to marking up for copying to form new editions. We also gain from this text a far clearer picture than before of the possibilities and realities of scholarly activity amongst intellectuals in imperial Rome, of the nature of library use and of the practices of book-copying, book-editing and book-circulation. ${ }^{7}$ Matters that remain debated are: whether or at what points Galen is referring to unique manuscripts from the collection of an illustrious collector (or even, in some cases, the autograph manuscripts of the author himself), as opposed to simply copies deriving from a particular, important manuscript tradition; and, in several cases, the precise identity of the works or authors in question. (On these points again, see the discussion of the problem passages of Greek below.)

The text has also brought new perspectives on broader questions related to the nature of both book production and book distribution in the GraecoRoman world. One new finding is the apparent existence of an early form of codex or paginated book, at least in the context of collections of drug recipes. ${ }^{8}$ A broader area is the (already much discussed) nature or practice of book 'publication' or distribution (ekdosis) in the ancient world, and the relationship between texts intended for different persons or uses. The text of $\pi \varepsilon p i$ à $\lambda u \pi i a \varsigma$ certainly provides new evidence on book copying; on book distribution; on the nature of Galen's own intentions and claims in relation to his own works; and, of course, on the extent of his actual losses in the fire - even if the evidence in none of these areas is easy to interpret. ${ }^{9}$

To move to topic (iii): some aspects of Galen's literary and scholarly activity have already been considered under (ii); but as regards his statements on the order, intention and nature of his own compositions, remarks both in Пвpi

these Aristotelian works, uniquely in Rome, in the second century AD, with the ancient tradition that Theophrastus' own collection of texts of the school was extant in Athens in the first century BC, from where it was brought to Rome by Sulla after his sack of the city (and subsequently formed the basis of Andronicus' scholarly work).

7 For interpretation of what Galen says in section 13 in relation to specific extant editions, in particular of Plato, see Gourinat, J.-B. (2008). 'Le Platon de Panétius: à propos d'un témoignage inédit de Galien', Philosophie Antique 8, 139-51 and Dorandi, T. (2010). "Editori" antichi di Platone', Antiquorum philosophia 4, 161-74.

8 This is the conclusion of Nicholls, M. (2010). 'Parchment Codices in a New Text of Galen', Greece and Rome 2:57, 378-86, followed by Nutton, Avoiding Distress, 87 n. 67 and BJP ad loc. A 'drug book' of this kind would, then, be a sort of proto-codex, something loosely bound in leather, to which further recipes could be added $a d$ hoc. But an alternative interpretation sees the diphthera rather simply as a leather folder containing recipes or lists of recipes.

9 These questions are discussed in detail in my chapter 'New Light and Old Books', in this volume. 
$\dot{\alpha} \lambda u \pi i \alpha \varsigma$ and in the previously missing parts of Lib. Prop. and of Ord. Lib. Prop. shed new light. The importance of the latter material, although it is included by V. Boudon-Millot in her very thorough 2007 edition and commentary on those works, has not been significantly discussed. It is of considerable interest in the light it sheds on Galen's own view of the order and relationship between certain of his central works; and further study is needed to bring these passages in relation to what Galen says about the books in question, and their place in his oeuvre, elsewhere. But some summary of the 'new' passages may be of value here.

In My Own Books, first: the previous lacuna (at XIX.108 K.) covered the transition from Galen's discussion of his works of anatomy (ch. $4[3]^{10}$ ) to that of his works of disease classification, which thus appeared abruptly, without any further chapter heading; they now appear some way into ch. 6 [3]; see further below. Thus, we previously arrived at De morborum differentiis (Morb. Diff.) in the middle of a discussion of works of anatomy, without any understanding of the relationship Galen intended between this work of disease classification and the immediately preceding, anatomical works. The Vlatadon manuscript adds a substantial amount of material both to the end of ch. 4 [3] and to the beginning of ch. 6 [3], while also adding a wholly new chapter 5 - as well as the chapter titles of both the latter. The new ch. 4 material completes Galen's account of his epitomes of Marinus', and then Lycus', anatomical works, before mentioning some more general anatomical works (interestingly including $D e$ partium homoeomerium differentia) and summing up by saying that all these teach the nature of the constitution (kataskeue $)$ of the parts of the body; and that what follows after these is the discussion of the activities (energeiai) and function (chreia) of each part.

Such, indeed, is the heading of ch. 5: 'in which books are contained the activities and functions of those parts which are made apparent in anatomy'. This is in itself of considerable interest: Galen is essentially isolating a category of physiological works (those which describe energeia and chreia), works which have a distinct position, logically and paedagogically, after anatomical works but before therapeutic ones - or, to be more precise, before a set of works which provide a curriculum 'leading up to' the therapeutic works. The chapter starts by listing the lost The Motion of the Chest and the Lungs, De causis

10 For My Own Books I give the new chapter number, resulting from the full text of Vlatadon 14, followed by the old chapter number in square brackets. The discrepancy that has arisen by ch. 4 [3] is not due to a substantive addition, but simply that of a new chapter title 3 , 'The books written after these', at XIX.17 K., just after the account of his return home, and of the reappearance at that stage of certain youthful works, and just before his summons to join the imperial party on campaign. 
respirationis and the lost De voce. Next is De motu musculorum. Arresting here is the previously unknown characterization of this work as covering, specifically, the activities of the soul - by contrast with De naturalibus facultatibus, mentioned next, which covers those of nature, as does Excretion of Urine. Belonging to the same theoria, too (by which is meant, presumably, the overall chapter topic rather than the narrower one 'of nature'), are: De usu pulsuum, De usu respirationis, An in arteriis sanguis contineatur, De purgantium medicamentorum facultate and, 'all that has been said on the leading-part ${ }^{11}$ of the soul and on the sources that manage us' in De placitis Hippocratis et Platonis (PHP). The reference to ten books of $P H P$, here, as opposed to the nine which we now possess, incidentally supports evidence which was already known from the Arabic translation of chapters 3 and 16 of the work, where the work is also mentioned. Indeed, the mention of $P H P$ here - alongside those other mentions in My Own Books, both in the chronological account and under the heading 'related to the philosophy of Plato - adds to our understanding of Galen's own view of the work within his oeuvre: that is, its status in relation to the teaching of activity and function. Finally, within the new chapter, we have De usu partium $(U P)$, which is described as 'following from all those mentioned'. This internal self-ordering of Galen's works relevant to anatomy and physiology, and in particular the precise nature of the distinction between discussions of activity (energeia) and those of function (chreia), are important points to consider in any attempt to understand the status and intention of his various scientific discussions of the human body. ${ }^{12}$

Turning to ch. 6: we are now in a position to understand the proper position of Morb. Diff., and a list of other works related to disease classification, within Galen's suggested order and, more than that, the nature of the whole category to which he claims that these works belong. They are those to be read, or understood, before The Therapeutic Method ( place that this gives to $M M$ is interesting in itself. We then see how the intellectual ground needed for the understanding of that medical magnum opus is built up, starting from element and mixture theory (De elementis ex Hippocratis sententia, the first two books of De temperamentis (Temp.)), then - though these are optional at this stage - book 3 of Temp. and the eleven books of the

11 But n.b. that the term hègemonikon here (155 Boudon-Millot) is supplied by BoudonMillot on the basis of the Arabic.

12 The passage is to be put alongside a similar remark within UP itself, at 6.12 (III.463 $\mathrm{K} .=\mathrm{i} .337,22-338,1 \mathrm{Helmreich}$ ), where again works on anatomy precede works on energeia, which precede discussions of chreia. 
great pharmacological work, Simples; then De optimo corporis nostri constitutione, De bono habitu, De inaequali intemperie.

The new material thus gives us a much clearer picture than before of an order of instruction which goes from anatomy, through physiology, to element theory and disease classification before reaching therapeutics - as well as of which specific works Galen regards as physiological in this sense (dealing with energeia and chreia).

That last sequence was, admittedly, already known from Ord. Lib. Prop. 2 where, however, before the discovery of the Vlatadon material, $M M$ itself did not make an appearance. It in fact appears, now, right at the beginning of the new material, that is, just after those works just mentioned in the previous paragraph - except that, rather confusingly, it is then followed by a considerable list of works which 'precede' it. These, again, to a considerable extent confirm what is now suggested in Lib. Prop. 6 [3], mentioning a set of works on disease classification, though the situation is more complex and, one is tempted to say, more rambling, here. The precise order in that other text - ironically, in a work which claims to focus precisely on the question of order - is much harder to follow than that in My Own Books. However, the insights which may arise from close study of this text remain unexplored. To take just one example: the text's construction of the category of a 'semiotic' branch of the art of medicine, divided into diagnostic and prognostic, and its discussion of a number of texts - in particular on pulse and on crises - in this context, is surely worthy of further consideration.

Topic (iv) has provoked a number of different studies, focussing varyingly on genre and ancient parallels, on social context and on philosophical analysis (or on some combination of these). Christopher Gill's 2010 book gave a serious analysis of aspects of $\pi \varepsilon p i \alpha \lambda \nu \pi i \alpha s$, contextualizing it both within Galen's other ethical work and within the tradition of ethical writing; a number have focussed on questions of genre and socio-literary context; and there has been discussion, too, of the work's position within Galen's philosophical writings. ${ }^{13}$ Certain new perspectives on the Galenic concept of lupe and his 'practical ethics' are certainly introduced by the work, though again there are passages which elude straightforward interpretation. Several chapters in the present book take forward the analysis of Galen's discussion in this ethical area.

Let us turn to topic (v). The discovery of the full Greek text may, arguably, not revolutionize our understanding of the work in question: a considerable portion was already extant in Greek, and where there were problems of

13 For further details of this bibliography see in this volume my chapter 'A New Distress', n. 3 . 
interpretation with this, the new source does not always resolve them. However, the new complete version of the text in Greek certainly corrects a number of errors, unclarities and distortions in the Arabo-Latin and Hebrew versions; and beyond that, I suggest, it adds fresh material of significant philosophical interest.

Some of this material has already received attention. As shown by Antoine Pietrobelli in his discussion of the opening chapters of the work, relevant passages had been significantly distorted for theological reasons in the 'translations' which were previously our only source for them; there were also some names which were simply garbled in those versions. ${ }^{14}$ These passages in fact offer an unambiguous assertion of the gods' direct influence on human affairs, including Galen's own: he has experienced the activity of the Dioscuri at sea, as well as Asclepius' personal interventions (in the latter case, admittedly, there are a couple of similar references elsewhere in the corpus). They also show Galen adopting a distinctive position in relation to religious scepticism and belief. Interesting here is Galen's alignment of his own views with those of Socrates. Although the text is both somewhat elliptical and far from perfectly transmitted, he appears by this to mean that he follows Socrates in his respect for traditional religious observance in general, and in his willingness to obey the specific instructions of Apollo in particular; and moreover that he contrasts this Socratic-Galenic combination of theism on the one hand and professed ignorance of abstract theological-metaphysical questions on the other with the more thoroughgoing agnosticism of Protagoras. ${ }^{15}$

14 See Pietrobelli, 'Galien agnostique', esp. 109-20. Apart from the occlusion of individual gods (Asclepius, Dioscuri) for ideological reasons, and the distortion of the argument in relation to Socrates and Protagoras (cf. esp. Pietrobelli's chart laying out the different versions at 109-11), the Arabo-Latin text sometimes just hopelessly distorts names, e.g. that of Empedocles as 'Elumerephilis' (vel sim.) at Prop. Plac. 7 (179,23 Boudon-Millot and Pietrobelli), or simply omits them, e.g. those of Plato and Chrysippus in the attribution of arguments on the incorporeal or corporeal nature of the soul at Prop. Plac. 7 (179,18 Boudon-Millot and Pietrobelli).

15 For both gods' personal interventions and the argument in relation to Socrates and Protagoras, see Prop. Plac. 2 (172,31-173,12 Boudon-Millot and Pietrobelli), with Pietrobelli (cited in the previous note). Pietrobelli's further argument that the text justifies a place for Galen in the history of 'agnosticism' seems to me overstated. Galen is agnostic in specific areas. This is already clear elsewhere in the corpus, although Prop. Plac. enriches the picture, elaborating the distinction between unknowable matters which provoke useless discussion and knowable matters, useful for medicine or ethics, with a third category, where arguments of plausibility may be advanced but where secure knowledge claims cannot be made; the last category is further understood as one where secure knowledge would hypothetically be an 'adornment' to the medical and ethical results achieved through things that do admit of precise knowledge (Prop. Plac. 14, 188,6-18 Boudon-Millot 
Other parts of the text await a more thorough analysis, which may, I suggest, contribute significantly to our analysis of Galen's mature medicalphilosophical thought in certain important areas. Those include: his epistemological views on the domain and limits of certainty; his formulation of his own views on certain central doctrinal areas (e.g. element theory, humoral theory, the nature of mixture) in relation to that epistemological framework; his understanding of the relationship of the soul, and of higher-level capacities more generally, to the body. ${ }^{16}$

The following is by no means an exhaustive account, either of every locus which has attracted a textual discussion, nor, in the case of those which have, of every individual emendation or interpretive suggestion that has been put forward. It does claim to present the most significant variant readings and interpretations of the most textually problematic passages, and especially for those where the differences are most significant for our understanding on points of substance. Not all of what follows is of equal interpretive significance; but I draw attention especially to points (c), (f) and (g), which address the major and much-discussed - problems regarding ancient libraries, books and editorial practices; and also points $(\mathrm{r}),(\mathrm{s})$ and $(\mathrm{t})$, which are of importance for the understanding of Galen's ethical position, in relation both to Stoicism and to the compromise with 'real life'. The method I follow in presenting these is to print the text which, after consideration, seems to me the most plausible, followed by an apparatus offering the most significant variant options, discussion of these variants and the related interpretations and, where necessary, English translation. (In one particularly complex and debated case, I have in the interests of readability presented two alternative versions of the Greek text, each followed by translation.)

and Pietrobelli). In terms of religious agnosticism, while Galen denies that we can know the substance of the gods (that is, there is very little we can say about their nature), on their existence and power in the natural world - on the validity of the argument from design - he has no doubt. There is similar agnosticism - again repeated throughout the corpus - on the substance of the soul.

16 A first attempt at such analysis is made in my forthcoming article, 'Galen on his Own Opinions: Textual Questions and Fresh Perspectives from Ms Vlatadon 14'. 
(a) The title

Пврі $\dot{\alpha} \lambda v \pi i \alpha \varsigma$

$\dot{\alpha} \lambda u \gamma(\sigma i \alpha \varsigma$ мs $\dot{\alpha} \lambda u \pi i \alpha \varsigma$ BM $\dot{\alpha} \lambda u \pi \eta \sigma i \alpha \varsigma$ BJP

Immediately in the title line we have an indication of the level of the scribal errors in this Ms and of the difficulties that will result from them. There may seem to be little interpretive significance in this case, but BJP argue that $\dot{\alpha} \lambda v \pi \eta \sigma^{\prime} \alpha$ (a noun formation paralleled by e.g. $\dot{\alpha} \circ p \eta \sigma^{\prime} \alpha, \dot{\alpha} \circ \chi \lambda \eta \sigma^{\prime} \alpha$ ) has a more active sense and is therefore more appropriate to the context of this work: while $\alpha \lambda v \pi$ i $\alpha$ properly means 'absence of distress', $\alpha \lambda \nu \pi \eta \sigma i \alpha$ would mean 'the activity of not being distressed'. In favour of BJP's reading is the fact that a lengthened form (although not the same lengthened form) appears at each of the four MS occurrences: here; at 69 (21,12 BJP: $\left.\alpha \lambda v \pi \varepsilon เ \sigma^{\prime} \alpha \varsigma\right)$; at $79 \mathrm{~b}(24,11 \mathrm{BJP}$ :

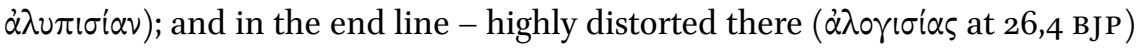
as it is in the title line. Against them is the fact that the emendation involves the positing of an otherwise unattested Greek word; the fact that the title appears in the more expected form Пвpi $\alpha \lambda u \pi i \alpha \varsigma$ in its mention in ch. 15 [12] of Lib. Prop. (XIX.45 K. = 169,17 Boudon-Millot); and evidence for the existence

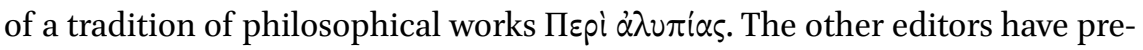
ferred the less challenging form.

\section{(b) Ind. $4(3,6-7 \mathrm{BJP})$

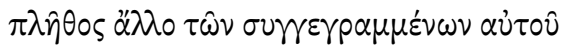

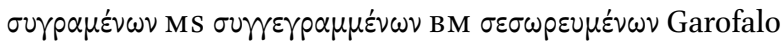

The more obvious emendation, adopted by BJP, seems to make this a reference to writings made in situ ('la masse de mes écrits rédigés ici même'); Nutton, finding this reference to place odd, follows Garofalo: 'a further mass of things stored there'. The significance of this latter reading is that if we accept it Galen is not then mentioning his own writings in this first listing of his losses, but only comes to them in a subordinate clause some twelve lines later. The notion that Galen is referring to his 'writings composed here' does not seem to me so problematic as to motivate the emendation to such a distant form, and I wonder whether in fact $\alpha \dot{v} \tau o \hat{v}$ has to be understood so literally as attached to $\sigma u \gamma \varepsilon \gamma p \alpha \mu \mu \varepsilon \dot{\varepsilon} \omega \nu$. With regard to the verb $\sigma \omega \rho \varepsilon \dot{v} \omega$, Galen uses this verb on several occasions, usually with a very concrete physical sense of 'pile up', rather than just 'store'. So, its use here is perhaps not supported by its occurrence a little later in this same text (where indeed it has that concrete, vivid sense), 10 (5,1-2

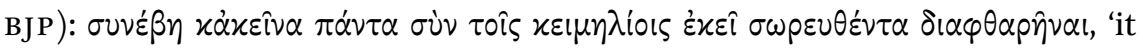


happened that they too [sc. the valuables from his own house] had all been piled up with the things stored there, and were destroyed'. If Galen in the second passage is essentially repeating the same information, with a little more detail - that is, referring to the same objects again, those that were added to what was usually in storage in preparation for his departure - this would support the reading $\sigma \varepsilon \sigma \omega \rho \varepsilon \nu \mu \varepsilon \dot{v} \omega \nu$; but he may, rather, be adding further information: not only were all these things that I have mentioned already destroyed, but also the valuables I had 'piled on' just recently. (Pace Roselli, ${ }^{17}$ the adverb $\alpha$ ป $\tau 0 \hat{v}$, given Galen's use of the verb $\sigma \omega p \varepsilon \dot{\omega} \omega$ in the concrete physical sense mentioned, rather supports the latter interpretation: the mention of a stock of items 'that I had piled up here' - meaning 'at Rome' would be slightly odd,

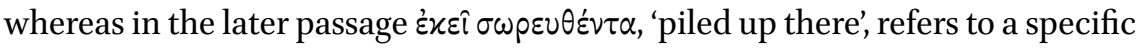
act of adding them to the storeroom.)

(c) Ind. $13\left(6,5^{-7} \mathrm{BJP}\right)$

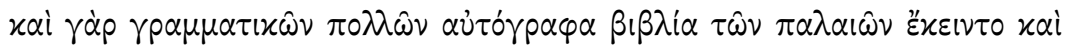

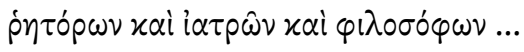

$\alpha \dot{\tau} \tau \dot{\gamma} \gamma \rho \alpha \varphi \alpha$ MS $\alpha \dot{v} \tau i \gamma p \alpha \varphi \alpha$ BJP

Here, faced with the apparently implausible claim that there were extant man-

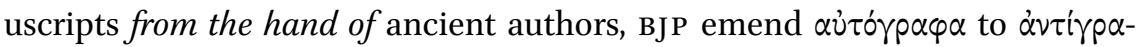
$\varphi \alpha$, and their translation thus yields the less challenging claim that there were 'copies' of many ancient grammarians, orators, etc.

Nutton defends the Ms reading on the grounds that it there may have been works which were at least thought to be from the hand of 'ancient' authors. He translates:

There were also many autograph copies of ancient grammarians, orators, doctors and philosophers ...

Manetti, however, has a quite different interpretation. Citing parallels on the usage of 'autograph' and similar terms, ${ }^{18}$ she offers an alternative translation

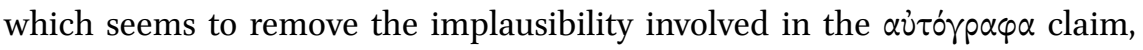
while preserving the ms reading:

\footnotetext{
17 Roselli, A. 'Libri e biblioteche a Roma al tempo di Galeno: la testimonianza del de indolentia', Galenos 4 (2010), 127-48.

18 Manetti, D. 'Galeno $\pi \varepsilon p i$ $\alpha \lambda v \pi i \alpha \varsigma$ e il difficile equilibrismo dei filologi', in Manetti, Studi, 15, citing in particular Fronto, Ad M. Caes. 1.7.4 (15,13-21 van den Hout).
} 
There were also the autograph manuscripts of many grammarians, [containing the texts of] ancient authors: orators, doctors and philosophers ...

On this view, the identity of these manuscripts as 'autographs' is indeed being asserted, but not as autographs by those authors. The perceived value of an ancient work could, as she argues, be hugely enhanced by the status of the person who copied it, especially when that was a distinguished scholar or grammarian. She thus separates the two sets of genitives in the above phrase: there are 'many grammarians' and then there are 'the ancients', with 'orators, doctors and philosophers' functioning as a gloss of the latter (an interpretation which perhaps also offers a more natural usage for the three iterations of $x$ ai). What is in question, then, is not the rather implausible autograph manuscripts of the ancients, but autograph manuscripts by distinguished grammarians of the ancients. This seems to me the most convincing solution.

(d) Ind. 14 (6,9-10 вJP)

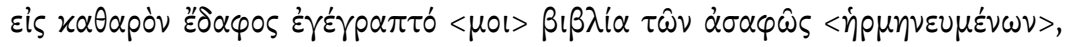
$\dot{\eta} \mu \alpha \rho \tau \eta \mu \dot{\varepsilon} v \omega \nu \delta \dot{\varepsilon} \kappa \alpha \tau \dot{\alpha} \tau \dot{\varsigma} \varsigma \gamma \rho \alpha \dot{\varphi} \alpha \varsigma$

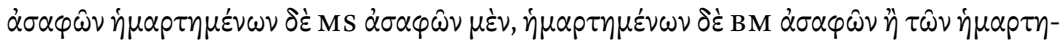
$\mu \varepsilon \dot{v} \omega \nu$ [om. $\delta \dot{\varepsilon}]$ Roselli $\alpha \sigma \alpha \varphi \omega \hat{~} \dot{\eta} \rho \mu \eta \nu \varepsilon u \mu \varepsilon \dot{\varepsilon} \omega \omega \nu$ scripsi

The description is clearly one of manuscripts which contained errors and of which Galen had laboured to produce error-free, 'clean' copies. There is a problem in the syntax, the $\delta \dot{\varepsilon}$ seeming to require a previous $\mu \dot{\varepsilon} v$, which в м supplied; but even then the text reads rather baldly. Roselli points out ${ }^{19}$ the relevance to this context of a passage from his commentary on the Hippocratic Nature of Man, in which Galen is similarly describing the unclarity that can arise in manuscripts; he attributes it to two causes: poor expression on the part of

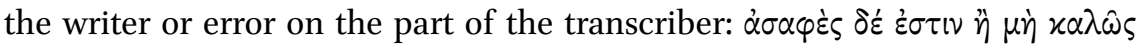

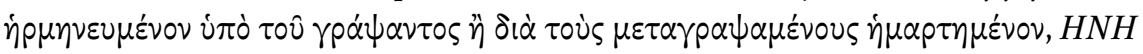
(xv.46 K. $=26,2-3$ Mewaldt). The fact that Galen seems to have two parallel phenomena in mind here, in conjunction with the similarity of the contexts,

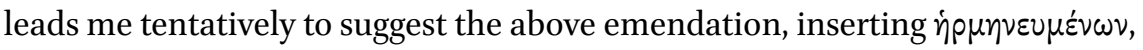
the omission of which through its similarity to the immediately following $\dot{\eta} \mu \alpha \rho \tau \eta \mu \varepsilon v \omega \nu$ would be a very easy error. It is true that one would prefer a different connection, perhaps reading $\tau \varepsilon$ for $\delta \dot{\xi}$; but the sense thus provided, that unclarity in the author's expression goes hand in hand with errors that require correction in the Mss, seems the right one.

Roselli, 'Libri', 141. 
(e) Ind. 15 (6,19 BJP)

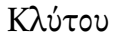

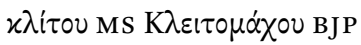

BJP (followed by KS and GL) emend to make this a reference to the secondcentury-BC Platonist Clitomachus; but as Rashed has shown (see n. 6 above), the context makes Clytus, an Aristotelian of the first generation, a much more likely choice: this also involves a minimal change to the ms reading. (The latter reading is also accepted by Nutton.)

(f) Ind. 16-17 (6,21-7,14 BJP)

The problems of this passage have been much discussed. Nutton gives a separate appendix to his translation (101-6); a substantially different interpretation is given by Manetti; Rashed also gives detailed commentary and emendations. In view of the complexities, I print two versions of the Greek text first, that on which Nutton bases his translation (that of BJP with very small changes), then one which adopts the changes suggested by Manetti (2012), followed by an apparatus (with line numbers referring to the first version here printed) and the relevant English translation in each case (mine, in the case of Manetti). Words corresponding to the most important differences in reading and interpretation have been highlighted in bold.

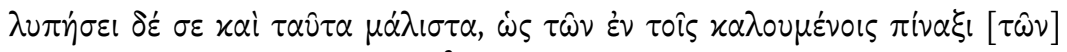

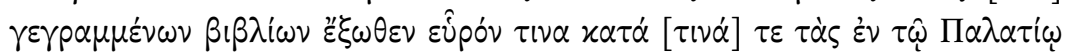

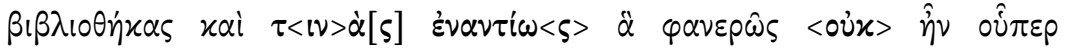

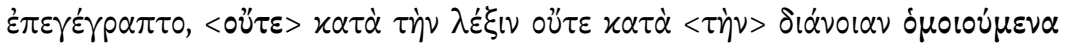

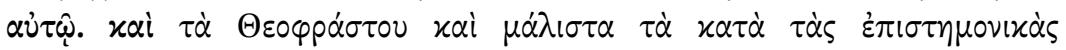

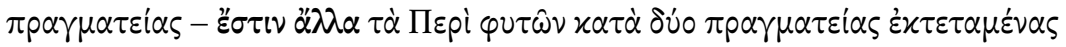

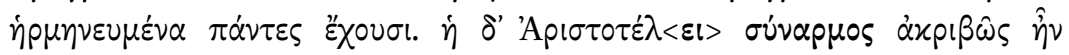

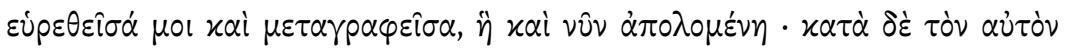

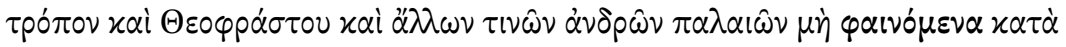

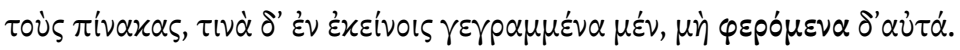

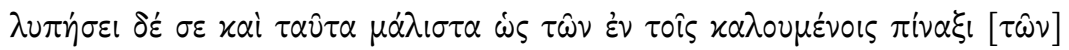

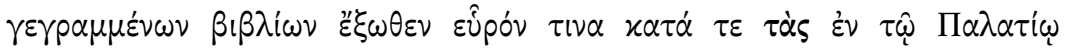

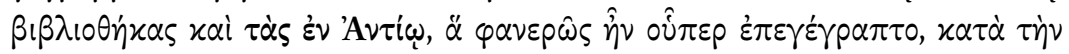

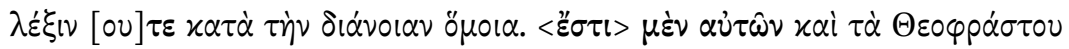

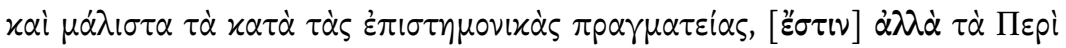

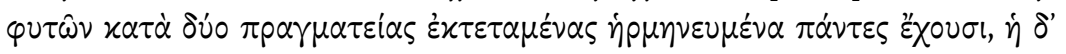




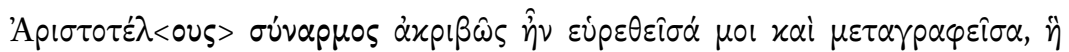

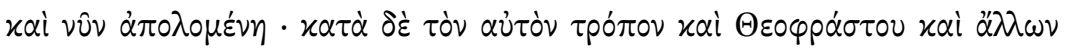

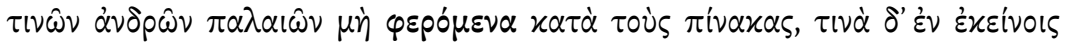

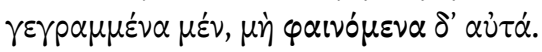

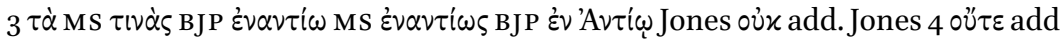

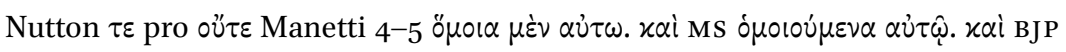

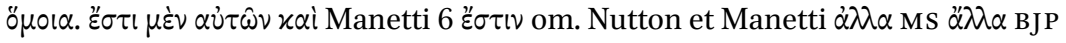

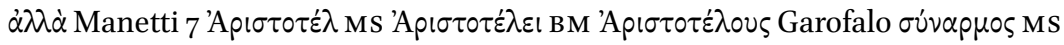

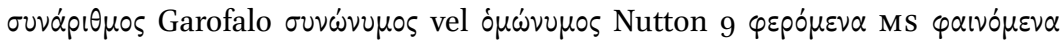

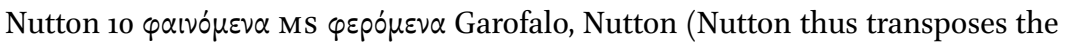
MS $\varphi \varepsilon \rho o ́ \mu \varepsilon v \alpha$ and $\varphi \alpha$ ivó $\mu \varepsilon v \alpha$; Garofalo reads $\varphi \varepsilon \rho o ́ \mu \varepsilon v \alpha$ twice.)

Nutton:

You will be particularly distressed to learn that I had found in the Palatine libraries some books not described in the so-called Catalogues and some, that were clearly not the work of the author whose name they bore, being similar neither in language nor in ideas. There were also writings of Theophrastus, and especially his books on science - the other books on plants, explicated in two long treatises, everyone has. There was also a work of the same name by Aristotle which I carefully found and transcribed but which is now also lost, and likewise works by Theophrastus and other ancient writers that did not appear in the Catalogues, as well as others that were mentioned there, but did not circulate widely.

\section{Manetti/Singer:}

You will be particularly distressed to learn that, beyond the books described in the so-called Catalogues, I found some, both in the Palatine libraries and in those in Antium, which clearly were the work of the author whose name they bore, being similar both in language and in ideas. Amongst them are the works of Theophrastus, and especially his books on science; but the works on plants, explicated in two long treatises, everyone has, while that of Aristotle was found by me immediately following on from that one [sc. that of Theophrastus], and transcribed, but is now lost. And in the same way I found works, both of Theophrastus and of certain other ancient writers which were not contained in the Catalogues, and some which were mentioned there, but were evidently not those works. 
Here there are three key differences: (1) the reading 'in Antium' (proposed by Jones and now widely discussed, but rejected by Nutton and Jouanna); (2) the change of negative to positive propositions in the places noted in bold (note that an emendation is required in either case: other editors have made sense by adding the second negative, 'neither'); (3) a different reconstruction of the beginning of the second sentence, and thus of its logical relationship with the first; (4) the interpretation of oúvapuos as 'contiguous', that is to say, 'physically part of the same manuscript' (and of the adverb $\alpha x p$ ifying that - i.e. 'immediately' contiguous - rather than referring to Galen's activity).

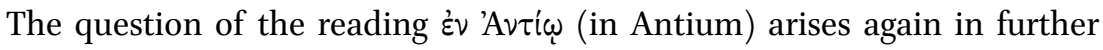
passages below. Without attempting to address all the arguments, one may point out (a) that a main strength of the reading $\dot{\varepsilon} v$ 'Avti $\omega$ is that it provides a linguistically satisfying solution to the problem presented by the MS of three separate occurrences of forms of the word हvavtios, none of which admits of an entirely convincing interpretation as such (see further below); (b) that in that case the subsequent discussion of losses due to misappropriation and to water damage would, in both cases, refer to what happened to the collection of this Antium library, rather than to, respectively, a library in Rome and (in a way which is seems difficult to explain) some of Galen's own books; (c) that whatever difficulties the 'Antium' interpretation presents - the main one, of course, is the lack of other evidence for a library in that location - it does thus solve both a linguistic puzzle and a difficulty in understanding the location, as well as explaining what is otherwise an unclear transition to an account of a different cause of damage to books which has nothing to do with fire (see further below).

From that point on, Manetti's readings enable her to reconstruct in a plausible way the connection between the general remark about the books that Galen had found and what follows about Theophrastus and Aristotle. It is some lost works of Theophrastus on science - works which clearly are in accord with his views - which he found, in spite of their not being in the 'catalogues'; there follows a parenthetical remark about Theophrastus' work on plants, which by contrast is widely available; and finally we come to the most valuable work lost, that of Aristotle on plants (as also accepted by Nutton), which Galen had found in the same manuscript as the equivalent work of Theophrastus. BJP, by contrast, take the reference to be to a work of Theophrastus which was per-

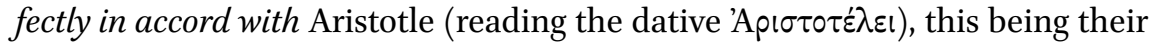
interpretation of the term sunarmos; but the exact nature of this book, and its relationship to the previous remark about plants, are then difficult, whereas 
the interpretation whereby this a lost work by Aristotle seems to make much better sense of the sentence as a whole.

The main differences of interpretation, then, are: (a) the identity of the book which Galen describes himself as having discovered and (b) the relationship of the books mentioned here in general to the libraries or their lists, ${ }^{20}$ which depends upon whether one adds two additional negatives to the sentence (with BJP and Nutton) or emends (with Manetti) to remove the existing negative. The latter seems to me to give clearly better sense: Galen is talking about works not contained in library catalogues, but which were evidently authentic works of the authors whose names they bore.

I note here, without going into all its details, the reconstruction of Rashed. This agrees with the above version of Manetti in essentials - the key point is the availability to Galen, before the fire, of works not in the catalogues, which nevertheless were apparently authentic works of ancient authors - but has a more elaborately emended version of the sentence containing the references to Theophrastus, leading however to the same essential conclusion, that Galen had access to and copied Aristotle's De plantis, which is now lost. (He emends

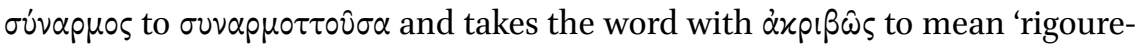
sement concordant'.) On the term ov́vapuos itself, it seems to me that (a) its usual meaning and (b) its non-appearance elsewhere in Galen argue strongly in favour of the view that it is in this specific context referring to a physical feature of a book, and thus in favour of the interpretation of the word as referring here to physical contiguity in a manuscript. The text in question was 'attached to', 'following on from', the other; this thus adds further to the plausibility of Manetti's reconstruction: Galen is here explaining the particular circumstances - attached to a manuscript of Theophrastus - in which he found this otherwise non-extant work of Aristotle.

Finally, on the last part of the passage, after $\dot{\alpha} \pi 0 \lambda \circ \mu \varepsilon \dot{v} \eta$. This part is not discussed by Manetti; the main point at issue is the reading and interpretation of the MS words $\varphi \varepsilon \rho o ́ \mu \varepsilon v \alpha$ and $\varphi \alpha i v o ́ \mu \varepsilon v \alpha$. As seen above, Nutton transposes the two terms, to give the sense 'did not appear ... did not circulate widely'. BJP have no trouble with $\varphi \varepsilon \rho o ́ \mu \varepsilon v \alpha$ in the sense of appearing in a catalogue ('n'étaient pas mentionnés'), and take the latter phrase in the sense 'avaient disparus'.

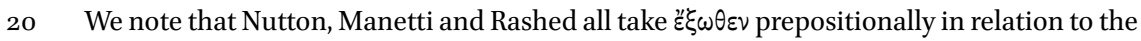
books which appeared in the pinakes: 'beyond' or 'not described in'. Manetti takes 'catalogues' (pinakes) here to refer simply to the library catalogues, since the famous listing of Andronicus, which has been suggested as the reference here, did, apparently, contain Aristotle's work on plants. 
Nutton's transposition seems unnecessary; but there is another point, which is that none of the existing interpretations seems to make good sense of the final word, $\alpha \dot{\tau} \tau \dot{\alpha}$. It seems that Galen is making the additional point that, as well as authentic works which were not in the catalogues (and which he found), there were also some books which were in the catalogues, but which were, in fact,

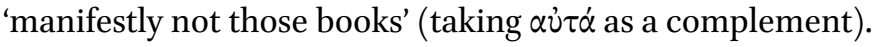

(g) Ind. 17 (7,14-16 вJP); 18 (8,3-6 в в $)$

One should, then, relatedly, consider the two remaining problematic places which give rise to the possible 'Antium' reading:

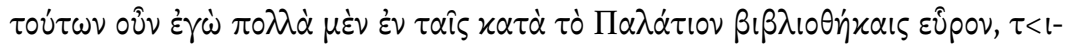
$\nu>\dot{\alpha} \delta^{\prime}$ 'ंv $\alpha \nu \tau i \omega \varsigma$ $\varkappa \alpha \tau \varepsilon \sigma \varepsilon \dot{v} \alpha \sigma \alpha$.

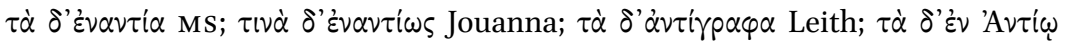
Jones

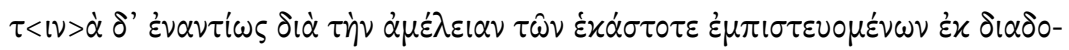

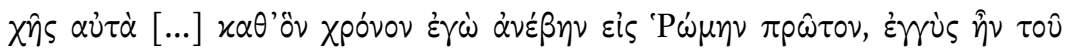
$\delta เ \varepsilon \varphi \theta \dot{\alpha} \rho \theta \alpha$.

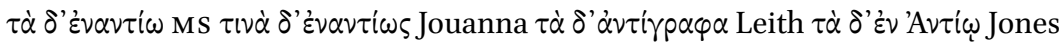

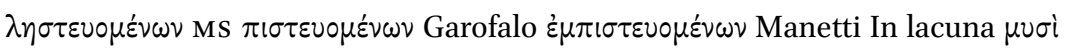
$\beta \varepsilon \beta \rho \omega \mu \varepsilon ́ v \alpha$ coni. Rashed

If one is not persuaded of Antium, one has a choice of a translation along the lines of 'à l'opposé', with BJP, or Leith's 'copies' - which perhaps works better with the verb, $\varkappa \alpha \tau \varepsilon \sigma \varepsilon v \alpha \sigma \alpha$, 'I procured' (or 'I had prepared'), at 7,16. ${ }^{21}$

In the second of these two passages, BJP are again forced to expand $\tau \dot{\alpha}$ to $\tau i \nu \grave{\alpha}$; and again Leith's $\tau \dot{\alpha} \delta^{\prime} \dot{\alpha}^{\prime} \tau \tau^{\prime} \gamma p \alpha \varphi \alpha$ is perhaps the most plausible non-Antium solution: the emendation itself makes much easier Greek than any of the attempts to make sense of some form of the word for 'opposite'; and it provides good sense in these two instances. (It seems to make less good sense in the earlier instance, discussed above at (f), because then the text would seem to say that he found both books in the Palatine libraries and copies, when it is precisely the destruction of the Palatine collection that is at stake.) In purely palaeographical terms, the distortion of the fairly common term $\alpha \dot{v} \tau i \gamma p \alpha \varphi \alpha$ is harder to explain than that of the unfamiliar place name Antium.

21 In this case Nutton presents the problem, but does not actually translate the phrase. 
In the remainder of this admittedly corrupt text, one has a choice between the carelessness of a succession of the [librarians] who are being robbed and the carelessness of the [librarians] who were successively entrusted with the books. Rashed's conjecture, based on a consideration of the precise length of the lacuna, as well as the possible discernibility of the letters $\mu, \sigma$ and I within it, has the manuscripts in question 'eaten by mice' rather than looted. (Rashed also accepts the Antium emendation.) The more fundamental question here remains, whether Galen is now talking about a completely different library, at Antium, or giving further information about depredations at Rome. In the passage immediately following the above, Galen talks specifically of damp ( $\sigma \eta \pi \varepsilon \delta \delta^{\circ} \circ \mathrm{S}, 8,9 \mathrm{BJP}$ ) as the cause of the fact that the manuscripts in question are now 'useless': they cannot be opened. This in turn is

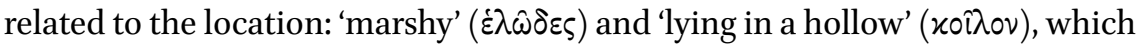
makes it 'stifling' ( $\pi v v$ rypóv) in summer $(8,10-11$ BJP). Nutton discusses the archaeological options in detail: it is possible that Galen is talking about some library, or library annex, undamaged by the fire but in a marshy area of the Forum; although it is the easiest emendation of the Greek to accept 'Antium' three times, there is no other evidence for a major library there. The above description of the location as 'marshy, lying in a hollow and stifling in summer' may also seem a major obstacle to the Antium theory: one would expect such a library to have been high up, overlooking the sea. But xoî̉ov may mean 'lying between cliffs', as well as 'in a hollow', and $\dot{\lambda} \hat{\omega} \delta \varepsilon \varsigma$ could perhaps be taken to refer to damp, rather than literally to a 'marshy' environment; and it is, presumably, possible that the specifics of the library's location or construction caused it to be both poorly ventilated ('stifling', $\pi v(\gamma \eta \rho o ́ v)$ and prone to damp.

(h) Ind. 26 (10,10 BJP)

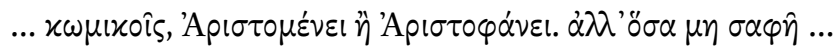

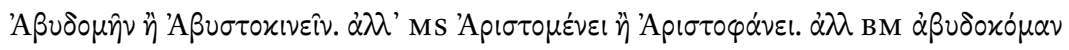

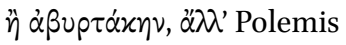

Polemis ends the sentence after $\varkappa \omega \mu \varkappa x o i \zeta$ and starts a new one with $\alpha \beta v \delta o x o ́ \mu \alpha v$

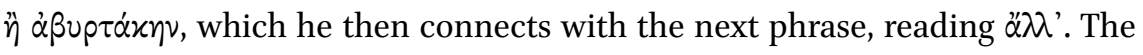
point is that these are obscure lexical items, exemplifying Galen's philological practice: 'Abudokoma and aburtakē, and all other unclear terms, were defined ...' The extreme distortion of the names Aristomenes and Aristophanes in the Ms, as well as the particular choice of Aristomenes, seems difficult to explain; and Polemis' ingenious emendation may well be correct. 
(i) Ind. $28(10,21-24 \mathrm{BJP})$

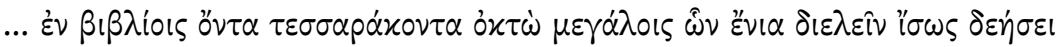

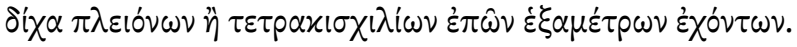

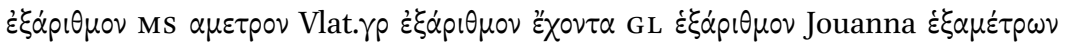

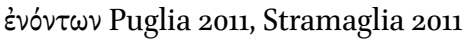

Galen, speaking of his forty-eight books on the vocabulary of Attic prose authors, adds that some of these may yet have to be divided into further books because of their length. Jouanna is surely right to prefer a form with rough breathing: the reference is to a hexameter line, which was used also as a unit of measurement for prose works, and $\dot{\xi} \dot{\alpha}$ p $\theta \mu \circ v$ makes little sense here. But $\dot{\varepsilon} \xi \dot{\alpha} \rho \bullet \mu \nu \nu$ is a fairly rare term, and the word $\dot{\xi} \xi \alpha \mu \dot{\varepsilon} \tau \rho \omega \nu$ - already implied by the superscript suggestion in the Ms - provides a more natural way for Galen to express this thought, as attested by his use of the very same phrase, $\dot{\varepsilon} \pi \hat{\omega} \nu$ $\dot{\varepsilon} \xi \alpha \mu \dot{\varepsilon} \tau \omega \nu$ (also in the context of line length within a prose work) at PHP 8

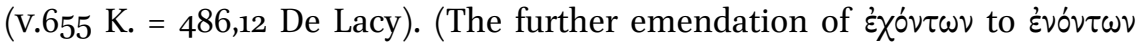
seems unnecessary: one might prefer it if the grammar more logically (as also

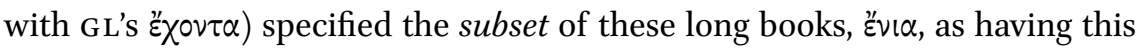
excessive length - but the sense is clear enough.)

(j) Ind. $32(11,19 \mathrm{BJP})$

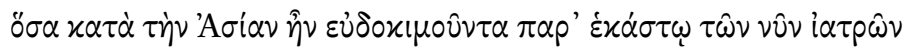

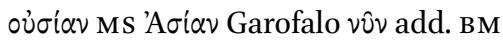

The context is that of a large collection of drugs, in the hands of someone who, it has been clarified, comes from Asia ( $\tau \hat{\omega} \nu \tau \alpha \rho^{\prime} \dot{\eta} \mu \hat{\imath} \nu, 11,15$ BJP). Garofalo's emendation, adopted by BJP and Nutton, seems plausible, and is printed here; at the same time, it seems to me not completely obvious that the Ms reading (according to which the drugs were valued 'by virtue of their substance', rather than 'in Asia') is to be rejected.

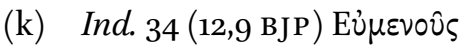

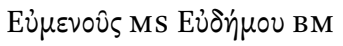

According to the Ms reading, Galen mentions a Pergamene doctor called Eumenes as the source of a collection of drug recipes which came into his possession, via another fellow Pergamene, Teuthras. The fact that this Eumenes is otherwise unknown, alongside the fact that Galen elsewhere mentions, in the 
specific context of drug recipes, a doctor called Eudemus, who was also from Pergamum, makes BM's emendation tempting; but both BJP and Nutton ad loc. argue against the identity on chronological grounds, and perhaps palaeographic caution should prevail.

(l) Ind. $39(13,12-15 \mathrm{BJP})$

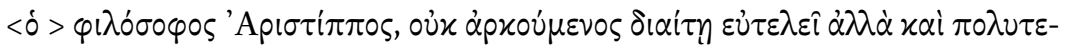

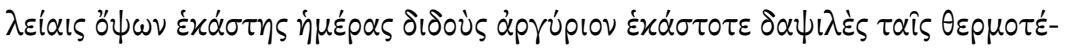

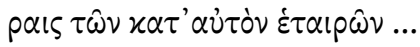

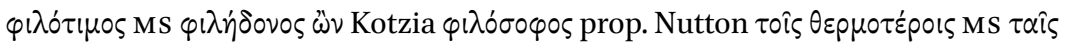

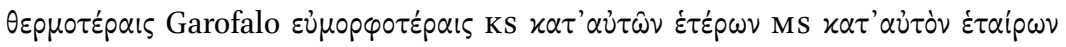

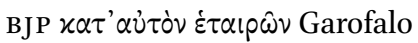

There are further, in particular syntactic, difficulties for the reconstruction of this sentence; but the main points at issue are: with what characterizing noun is Aristippus being introduced, and is he shown lavishing banquets and money on male associates or on courtesans? What is at stake is the precise nature of the example that Aristippus is thought to be offering. BJP defend the MS

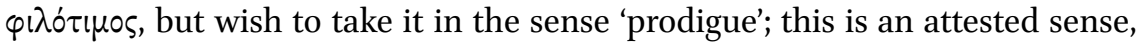
but the frequent occurrence of the term and its cognates in Galen, always with reference to a concern for one's own reputation, renders such an interpretation implausible. Ks's $\varphi(\lambda \eta \dot{\delta} \delta$ vos ('pleasure-loving', Nutton) certainly makes sense; but on balance the admittedly flat $\varphi 1 \lambda$ ó $\sigma 0 \varphi$ os, suggested by Nutton (though not adopted in his translation), seems the most likely solution. As for the question of companions (or pupils) versus prostitutes: the use of the adjective $\theta \varepsilon p \mu o$ s would seem very strange in relation to the former: its usual sense in relation to character is 'hot-headed'. This, in conjunction with the literary tradition on Aristippus' associations with prostitutes, seems - pace BJP, and though $\theta \varepsilon p \mu o ́ s$ as an adjective referring to the mores or appearance of women is not very clearly attested - to me to justify Garofalo's emendation, also followed by Nutton.

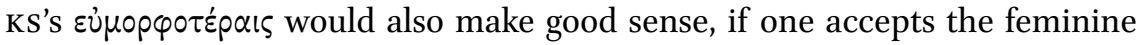
interpretation, but is harder on the basis of the Ms.

(m) Ind. 50a (16,8-10 вJP)

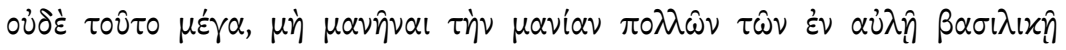

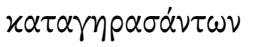

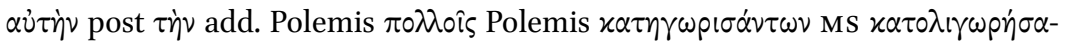

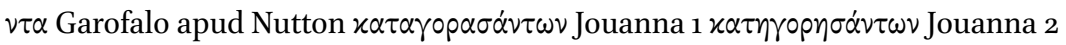

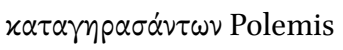


Amid many suggestions as to the form of the participle here, Polemis' seems to give the best sense: Galen is commenting on the 'madness' of 'many who have grown old in the imperial court', and this seems in keeping with his remarks elsewhere on the corruption attendant on a life concerned with social or political advancement. (Polemis' other emendations, to give the sense 'the same madness as many who ...', seem to me unnecessary; he is followed by GL on all points.) Jouanna's earlier suggestion, with the sense, 'ceux qui flânent dans la cour du palais', was superseded by that adopted in BJP, whereby the phrase from $\pi \circ \lambda \lambda \omega \hat{\omega} \nu$ would be a genitive absolute with the sense 'malgré le nombre des accusateurs à la cour impériale'. Nutton, finally, prefers Garofalo's earlier emendation, and translates 'since I cared little for life at the Imperial court'. But all the suggestions apart from that of Polemis (and Jouanna 1) require $\tau \dot{\nu} \nu \mu \alpha v^{\prime} \alpha \nu$ to stand alone in an implausible way: it is surely closely dependent on the participle that follows: 'the madness of those who .... (Nutton translates 'the madness of most people, since ...'; but this would require the further insertion of $\tau \hat{\omega} \nu$ before $\pi \circ \lambda \lambda \hat{\omega} \nu$.)

\section{(n) Ind. $5^{2}(16,21-2 \mathrm{BJP})$

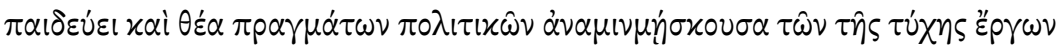

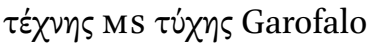

A choice must be made here between two terms which frequently appear as opposites in the philosophical discourse of Galen's time. In spite of BJP's spirited defence of the Ms reading, 'observation of the deeds of art' simply does not fit this context, where it is precisely the praemeditatio malorum, a consideration of all that may go wrong - focussing here especially on the 'random' nature of political or everyday events - which is recommended to the reader: 'reminding us of the actions of chance' (Nutton) is surely the right sense.

(o) Ind. 52 (17,5 BJP); repeated at 77 (23,8 BJP)

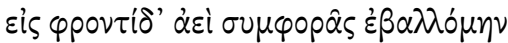

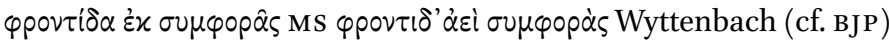

There are a number of variants in the ancient transmission of this extract from a non-extant play of Euripides, which is cited also by Plutarch and elsewhere by Galen himself at PHP 4 (V.418 K. $=282,18-23$ De Lacy). The problems are discussed at length by вJP ad loc. But in this particular line, although the $\dot{\varepsilon} x$ of the $\mathrm{MS}$ is in need of emendation, the genitive singular seems to me to give a prefer-

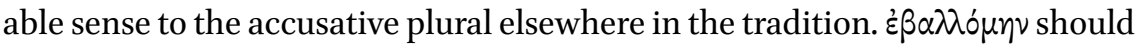


be taken as medio-passive intransitive: 'I used to be thrown/throw myself'; and

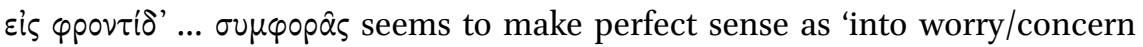
about disaster'. The alternative, preferred by BJP, takes $\dot{\varepsilon} \beta \alpha \lambda \dot{o}_{\mu \eta \eta \nu}$ as transitive with $\sigma \nu \mu \varphi \circ \rho \alpha \varsigma s$ as its object: 'I used to throw disasters into my mind'. This seems to me less natural, and $\varphi$ povtic usually has a sense of sense of 'worry', 'concern' or 'thought', rather than 'mind' as a receptacle for thoughts. (On the other

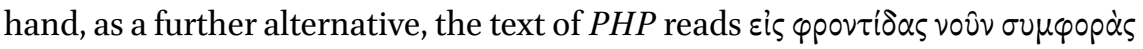
$\left.\tau^{\prime} \dot{\varepsilon} \beta \alpha \lambda \lambda o ́ \mu \eta \nu.\right)$

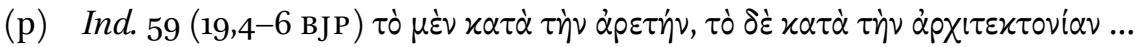

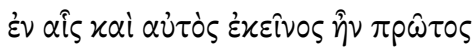

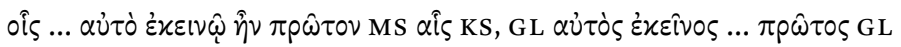

BJP follow the MS, translating: 'domaines dans lesquel la conduite (morale) était aussi, aux yeux de cet homme-là, primordiale', taking aùtò as referring

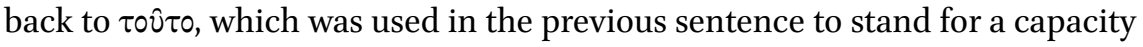
or respect for justice and self-control. But the phrase seems tortured, and it is difficult to see what sense can be made of the conceptual extension of this capacity to the domains of 'virtue and architecture'. GL's emendation - so, 'in which domains that very man, too, was pre-eminent' - seems to be demanded on linguistic grounds, and makes perfect sense in the context of the argument relating both to his own family's virtues and the nature and importance of early nurture and natural endowments.

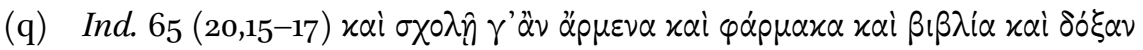

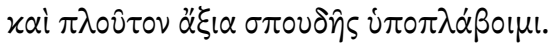

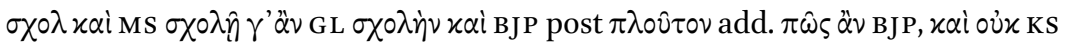

Galen is listing material or social goods which, as a result of his rearing and reasoning, he sets at a low rate. 'Leisure', in such a list as this, seems simply out of place, while $\sigma \chi 0 \lambda \hat{n}$ in the sense 'hardly' ('figurarsi', GL) seems clearly to provide the required sense: 'I would hardly take instruments, medicines, etc., to be worth the expense of energy' The reading also obviates the need for BJP's or Ks's insertion of further words.

(r) Ind. 70 (21,13-15 BJP)

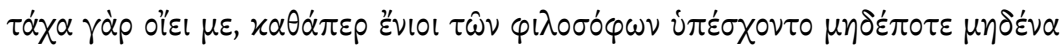

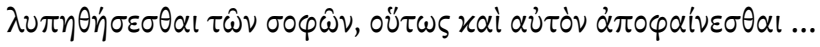




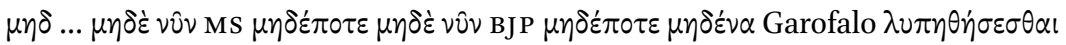

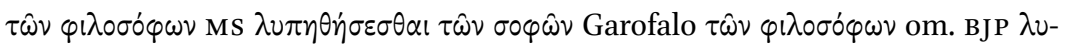

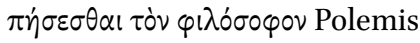

The MS repetition of $\tau \hat{\omega} \nu \varphi(\lambda \circ \sigma o ́ \varphi \omega \nu$ has been universally agreed to be problematic; BJP omit it, giving the sense, 'certain philosophers have promised that they will not be distressed, even in present circumstances'. But Garofalo's replacement of the second occurrence with $\tau \hat{\omega} v \sigma \circ \varphi \hat{\omega} v$, in conjunction with the easy emendation of $\mu \eta \delta \dot{\varepsilon} v \hat{v} v$ to $\mu \eta \delta \varepsilon \varepsilon \alpha$, surely gives the right sense. Galen is, as throughout this passage (see also the next text, (n) below), casting doubt on the specific claim made by some philosophers (in particular Stoics) that the

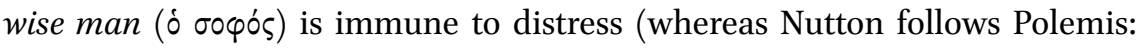
'that the philosopher will never suffer distress').

(s) Ind. $76(23,2-4 \mathrm{BJP})$

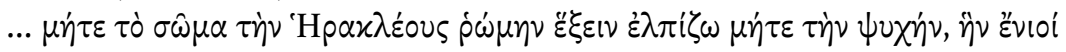

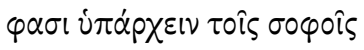

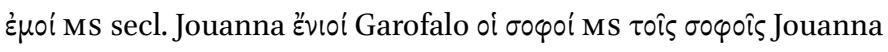

The context is that of adjusting one's aspirations, for both physical and ethical health, to one's own capacities: Galen states that he does not aspire for his body to have the strength of a Hercules, nor for his soul to have that - on the Ms reading - 'which the wise state that I have'. Both the introduction of 'the wise' as a class of people passing judgement on Galen, and the sense, contradicting the main force of the sentence, seem impossible. Taking Jouanna's

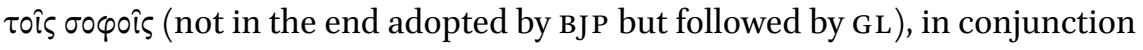
with Garofalo's हैvioi for ह̇ $\mu 0^{i}$ ), we gain the the sense 'which some state that the wise have', which is surely preferable. On this interpretation Galen is here also returning to the theme raised by the statement five sections earlier, 'I cannot say if there is anyone so wise (бo५ós) as to be totally unaffected' (71, 21,17-18 $\mathrm{BJP}$ ), and continuing the tone, anti-Stoic or at least critical of Stoic attitudes and aspirations, that runs through this whole passage. (Cf. also the previous passage discussed, (r).)

(t) Ind. $80-81(25,4-8$ вJP $)$

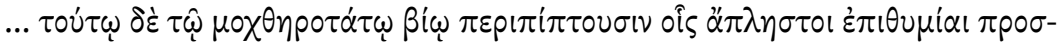

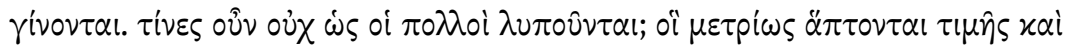

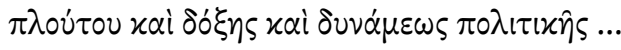




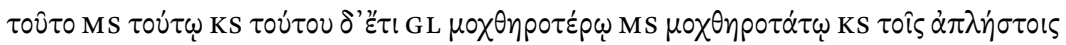

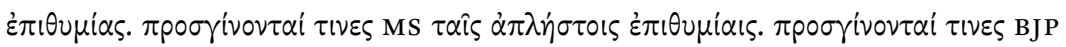

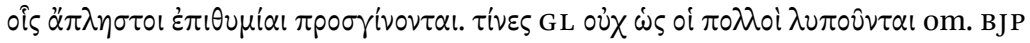

Both KS and GL depart from the MS and from BJP (and Nutton), in starting a

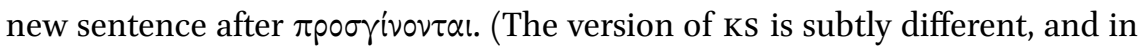
particular prints $\tau \imath v \varepsilon \grave{\zeta}$, starting a new sentence which is not a question.) Such a solution obviates the need to delete the whole phrase oủ $\chi \dot{\omega} \varsigma$ oi $\pi \circ \lambda$ oi $\lambda v \pi 0 v 0 \tau \alpha \mathrm{l}$, and seems convincing both in the better sense it gives for $\pi p \circ \sigma \gamma^{i} v 0 v \tau \alpha$ and in the clear relationship it presents between non-attachment (or only moderate attachment to worldly goals) and freedom from distress. The sense is thus not: 'they succumb to this wretched form of life through insatiable desires. There then also come some who have a moderate attachment to honour, wealth, reputation and political power', but: '... to this most wretched form of life succumb those in whom insatiable desires arise. Who, then, are the ones who do not suffer distress as others? Those who have a moderate attachment to honour, wealth, reputation and political power .... On this interpretation Galen is, to be sure, conceding more to the acceptability of attachment to material values than he does usually; but this is perhaps in keeping with the particular rhetorical stance he takes in this text in relation to Stoic views, on the one hand, and practically attainable life goals, on the other.

\section{Acknowledgements}

The author gratefully acknowledges the financial support of the Wellcome Trust and the Alexander von Humboldt-Stiftung during the research and writing of this paper. Heartfelt thanks go also to the editor, Caroline Petit, for her invitation to participate in the conference from which this chapter arose, and especially for her very helpful advice and encouragement during its subsequent development. The faults which it retains are, of course, my own.

\section{References}

\section{Secondary Literature}

Alexandru, S. 'Newly Discovered Witness Asserting Galen's Affiliation to the Gens Claudia', Annali della Scuola Normale Superiore di Pisa, ser. 5, 3/2 (2011), 385-433. Boudon-Millot, V. (ed., trans. and notes) Galien, Tome I, Paris: Les Belles Lettres, 2007. 
Boudon-Millot, V. 'Un traité perdu de Galien miraculeusement retrouvé, le Sur l'inutilité de se chargriner: texte grec et traduction française'. In La science médicale antique: nouveaux regards (Études réunies en l'honneur de Jacques Jouanna), ed. V. BoudonMillot, A. Guardasole and C. Magdelaine, 73-123. Paris: Éditions Beauchesne, 2007.

Boudon-Millot, V. 'Vlatadon 14 and Ambrosianus Q3: Two Twin Manuscripts'. In Galen's De indolentia, ed. C. K. Rothschild and T. W. Thompson, 41-55. Tübingen: Mohr Siebeck, 2014.

Boudon-Millot, V. and Pietrobelli, A. 'Galien ressuscité: édition princeps du texts grec du De propriis placitis', Revue des Études Grecques 118 (2005), 168-213.

Boudon-Millot, V. and Jouanna, J. (ed. and trans.), with A. Pietrobelli, Galien, Oeuvres 4: Ne pas se chagriner. Paris: Les Belles Lettres, 2010.

Dix, T. K. and Houston, G. W. 'Public Libraries in the City of Rome: From the Augustan Age to the Time of Diocletian'. In Mélanges de l'École Française de Rome. Antiquité 118:2 (2006), 671-717.

Dorandi, T. “Editori” antichi di Platone', Antiquorum philosophia 4 (2010), 161-74.

Fedeli, P. 'Biblioteche private e pubbliche a Roma e nel mondo romano'. In Le biblioteche nel mondo antico e medievale, ed. G. Cavallo, 48-64. Bari: Laterza, 1988.

Gourinat, J.-B. 'Le Platon de Panétius: à propos d'un témoignage inédit de Galien', Philosophie Antique 8 (2008), 139-51.

Houston, G. W. 'Galen, His Books and the Horrea Pipertaria at Rome', Memoirs of the British Academy in Rome 48 (2008), 45-51.

Jones, C. P. 'Books and Libraries in a Newly-Discovered Treatise of Galen', Journal of Roman Archaeology 22 (2009), 390-97.

Kotzia, P. 'Galen $\pi \varepsilon p i ~ \alpha \lambda \jmath \pi i \alpha \varsigma:$ Title, Genre and Two Cruces'. In Studi sul De indolentia di Galeno, ed. D. Manetti, 69-91. Pisa and Rome: Fabrizio Serra Editore, 2012.

Kotzia, P. and Sotiroudis, P. 'Г $\alpha \lambda \eta v 0 \hat{~ \pi \varepsilon p i ~} \alpha \lambda v \pi i \alpha \varsigma^{\prime}$, Hellenica 60 (2010), 63-148.

Manetti, D. 'Galeno $\pi \varepsilon p i ~ \alpha \lambda \nu \pi i \alpha \varsigma$ e il difficile equilibrismo dei filologi.' In Studi sul De indolentia di Galeno, ed. D. Manetti, 9-22. Pisa and Rome: Fabrizio Serra Editore, 2012. Manetti, D. (ed.) Studi su Galeno: scienza, filosofia, retorica e filologia. Atti del seminario, Firenze, 13 novembre 1998. Florence: SAMERL, 2000.

Manetti, D. (ed.) Studi sul De indolentia di Galeno, Pisa and Rome: Fabrizio Serra Editore, 2012.

Mastro, G. del 'Mé $\gamma \alpha \beta ı \beta \lambda$ íov: Galeno e la lunghezza dei libri'. In Studi sul De indolentia di Galeno, ed. D. Manetti, 33-62. Pisa and Rome: Fabrizio Serra Editore, 2012.

Nicholls, M. 'Parchment Codices in a New Text of Galen', Greece and Rome 2:57 (2010), 378-86.

Nicholls, M. 'A Library at Antium?' In Galen's De indolentia, ed. C. K. Rothschild and T. W. Thompson, 65-78. Tübingen: Mohr Siebeck, 2013.

Nutton, V. (ed. and trans.) Galen: De propriis placitis, Berlin: Akademie Verlag (CMG V 3,2), 1999 . 
Nutton, V. (trans. with introduction) Avoiding Distress, in Galen: Psychological Writings, ed. P. N. Singer, 43-106. Cambridge: Cambridge University Press, 2013.

Nutton, V. 'What's in a Nomen? Vlatadon 14 and an Old Theory Resuscitated'. In The Frontiers of Ancient Science: Essays in Honour of Heinrich von Staden, ed. B. Holmes and K.-D. Fischer, 451-62. Berlin: de Gruyter, 2015.

Pietrobelli, A. 'Variation autour du Thessalonicensis Vlatadon 14: un manuscrit copié au Xénon du Kral, peu avant la chute de Constantinople'. Revue des Études Byzantines 68 (2010), 95-126.

Pietrobelli, A. 'Galien agnostique: un texte caviardé par la tradition', Revue des Études Grecques 126 (2013), 103-35.

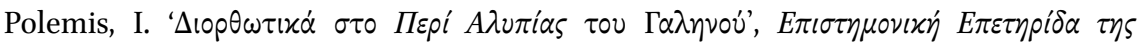

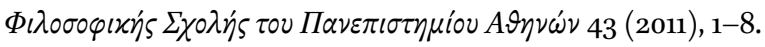

Puglia, E. 'La rovina dei libri di Anzio nel “De indolentia” di Galeno', Segno e testo 9 (2011), 55-62.

Rashed, M. 'Aristote à Rome au IIe siècle: Galien, De indolentia §§ 15-18.' Elenchos 32 (2011), 55-77.

Roselli, A. 'Congetture inedite', Galenos 2 (2008), 137-8.

Roselli, A. 'Libri e biblioteche a Roma al tempo di Galeno: la testimonianza del de indolentia', Galenos 4 (2010), 127-48.

Roselli, A. 'Galeno dopo l'incendio del 192: bilancia di una vita'. In Studi sul de indolentia di Galeno, ed. D. Manetti, 93-102. Pisa and Rome: Fabrizio Serra Editore, 2012.

Rothschild, C. K. and Thompson, T. W. 'Galen's On the Avoidance of Grief: The Question of a Library at Antium', Early Christianity 2.1 (2011), 11-29.

Singer, P. N. Galen: Selected Works. Translation with introduction and notes. Oxford: OUP, 1997.

Singer, P. N. (ed.) Galen: Psychological Writings: Avoiding Distress, The Diagnosis and Treatment of the Affections and Errors Peculiar to Each Person's Soul, Character Traits and The Capacities of the Soul Depend on the Mixtures of the Body, translated with introduction and notes by V. Nutton, D. Davies and P. N. Singer, with the collaboration of Piero Tassinari. Cambridge: CUP, 2013.

Singer, P. N. 'Galen on his Own Opinions: Textual Questions and Fresh Perspectives from MS Vlatadon 14', forthcoming.

Stramaglia, A. 'Libri perduti per sempre: Galeno, De indolentia 13; 16; 17-19'. Rivista di Filologia e di Istruzione Classica 139 (2011), 1-30.

Tucci, P. L. 'Galen's Storeroom, Rome's Libraries and the Fire of AD 192.' Journal of Roman Archaeology 21 (2008), 133-92.

Tucci, P. L. 'Antium, the Palatium and the Domus Tiberiana Again.' Journal of Roman Archaeology 22 (2009), 398-401. 
Tucci, P. L. 'Galen and the Library at Antium: The State of the Question', Classical Philology 108:3 (2013), 240-51.

Vegetti, M. Galeno: nuovi scritti autobiografici. Rome: Carocci, 2013.

\section{Texts: Editions, Translations and Abbreviations}

Editions and Translations of $\pi \varepsilon p i \quad \alpha \lambda v \pi i \alpha \varsigma$, with Abbreviation used in this Chapter

\section{Editions}

в м: Boudon-Millot, V. 'Un traité perdu de Galien miraculeusement retrouvé, le Sur l'inutilité de se chagriner: texte grec et traduction française'. In La science médicale antique: nouveaux regards (Études réunies en l'honneur de Jacques Jouanna), ed. V. Boudon-Millot, A. Guardasole and C. Magdelaine, 73-123. Paris Éditions Beauchesne, 2007.

BJP: Boudon-Millot, V. and Jouanna, J. (ed. and trans.), with A. Pietrobelli, Galien, Oeuvres 4: Ne pas se chagriner. Paris: Les Belles Lettres, 2010.

GL: Garofalo, I. and Lami, A. (ed. and trans.) Galeno: L'anima e il dolore. (De indolentia, De propriis placitis). Milan: Rizzoli, 2012.

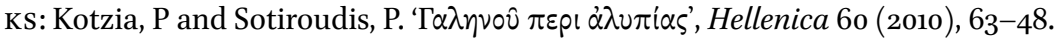

\section{Translations}

Nutton: Nutton, V. Avoiding Distress, in Galen: Psychological Writings, ed. P. N. Singer, 43-106. Cambridge: Cambridge University Press, 2013.

Rothschild, C. K. and Thompson, T. W. 'Galen: "On the Avoidance of Distress"'. In Galen's De indolentia, ed. C. K. Rothschild and T. W. Thompson, 21-36. Tübingen: Mohr Siebeck, 2013.

\section{Editions, Translations and Abbreviations of Other Works of Galen}

Texts of Galen are cited by volume and page number in Kühn's edition, followed where available by page and line number in the most recent critical edition.

K. = C. G. Kühn, Claudii Galeni Opera Omnia, 22 vols. Leipzig, 1821-1833. CMG $=$ Corpus Medicorum Graecorum, Leipzig and Berlin, 1908-.

$H N H=$ In Hippocratis De natura hominis. [K. Xv]. Ed. J. Mewaldt. Leipzig and Berlin: Teubner, CMG V 9,1, 1914.

Lib. Prop. $=$ De libris propriis (My Own Books). [K. XIX]. Ed. V. Boudon-Millot. Paris: Les Belles Lettres, 2007; trans. in Singer, Galen: Selected Works. 
$M M=$ De methodo medendi. (The Therapeutic Method). [K. X]. Trans. I. Johnston and

G. H. R. Horsley. Cambridge, Mass.: Harvard University Press (Loeb), 2011.

Mor. $=$ De moribus (Character Traits). [Not in K.]. Ed. Kraus, 'Kitāb al-Akhlāq', trans.

D. Davies in Singer, Galen: Psychological Writings.

Morb. Diff. = De differentiis morborum. [K. VI].

Ord. Lib. Prop. = De ordine librorum propriorum (The Order of My Own Books). [K. XIX].

Ed. V. Boudon-Millot. Paris: Les Belles Lettres, 2007; trans. in Singer, Galen: Selected Works.

PHP = De placitis Hippocratis et Platonis (The Doctrines of Hippocrates and Plato). [K. v]. Ed. and trans. P. De Lacy, 3 vols. Berlin: Akademie Verlag, CMG V 4,1,2, 1978-84.

Prop. Plac. $=$ De propriis placitis (My Own Doctrines). [Not in K.]. Ed. and trans.

V. Nutton. Berlin: Akademie Verlag (CMG V 3,2), 1999. Ed. and French trans. of fuller text by V. Boudon-Millot and A. Pietrobelli, A., 'Galien ressucité: édition princeps du texte grec du De propriis placitis', Revue des Études Grecques 118 (2005), 168-213. Ed. with Italian trans. by I. Garofalo and A. Lami ('GL' above). Ed. with Italian trans. by M. Vegetti, Galeno: nuovi scritti autobiografici. Rome: Carocci, 2013.

$Q A M=$ Quod animi mores corporis temperamenta sequantur (The Soul's Dependence on the Body). [K. IV]. Ed. I. Müller, in C. Galeni Scripta Minora, 2. Leipzig: Teubner, 1891; trans. in Singer, Galen: Psychological Writings.

Temp. = De temperamentis. (Mixtures). [K. I]. Ed. G. Helmreich. Leipzig: Teubner, 1904 . $U P=$ De usu partium. [K. III-IV]. Ed. G. Helmreich. Leipzig: Teubner, 2 vols, 1907-9; English trans. by M. T. May, Galen: On the Usefulness of the Parts of the Body. Ithaca, NY: Cornell University Press, 1968.

Abbreviations and editions of other texts Fronto

Ad M. Caes. = Epistulae ad Marcum Caesarem et invicem. Ed. M. P. J. van den Hout in M. Cornelii Frontonis Epistulae. Leiden: Brill, 1954. 